\title{
Airflow obstruction in young adults in Canada
}

\author{
Manal Al-Hazmi MD¹, Kate Wooldrage BSc ${ }^{1}$, Nicholas R Anthonisen MD¹, Margaret R Becklake MD², \\ Dennis Bowie $M D^{3}$, Moira Chan-Yeung MD , Helen Dimich-Ward $\mathrm{PhD}^{4}$, Pierre Ernst $\mathrm{MD}^{2}$, Jure Manfreda $M D^{1}$, \\ Malcolm R Sears $M B^{5}$, Hans C Siersted $M D^{5}$, Lamont Sweet $M D^{6}$, Linda Van Til DVM ${ }^{6}$
}

\begin{abstract}
M Al-Hazmi, K Wooldrage, NR Anthonisen, et al. Airflow obstruction in young adults in Canada. Can Respir J 2007;14(4):221-227.
\end{abstract}

OBJECTIVE: Airflow obstruction is relatively uncommon in young adults, and may indicate potential for the development of progressive disease. The objective of the present study was to enumerate and characterize airflow obstruction in a random sample of Canadians aged 20 to 44 years.

SETTING: The sample $(\mathrm{n}=2962)$ was drawn from six Canadian sites.

DESIGN: A prevalence study using the European Community Respiratory Health Survey protocol was conducted. Airflow obstruction was assessed by spirometry. Bronchial responsiveness, skin reactivity to allergens and total serum immunoglobulin E were also measured. Logistic regression was used for analysis.

RESULTS: Airflow obstruction was observed in $6.4 \%$ of the sample, not associated with sex or age. The risk of airflow obstruction increased in patients who had smoked and in patients who had lung trouble during childhood. Adjusted for smoking, the risk of airflow obstruction was elevated for subjects with past and current asthma, skin reactivity to allergens, elevated levels of total immunoglobulin $\mathrm{E}$ and bronchial hyper-responsiveness. Of the subjects with airflow obstruction, $21 \%$ were smokers with a history of asthma, $50 \%$ were smokers without asthma, 12\% were nonsmokers with asthma and $17 \%$ were nonsmokers with no history of asthma. Bronchial hyperresponsiveness increased the prevalence of airflow obstruction in each of these groups.

CONCLUSION: Smoking and asthma, jointly and individually, are major determinants of obstructive disorders in young adults. Bronchial hyper-responsiveness contributes to obstruction in both groups.

\section{L'obstruction des voies aériennes chez les jeunes adultes du Canada}

OBJECTIF : L'obstruction des voies aériennes est relativement rare chez les jeunes adultes, et elle peut indiquer la possibilité d'apparition d'une maladie évolutive. La présente étude visait à énumérer et à caractériser l'obstruction des voies aériennes auprès d'un échantillon aléatoire de Canadiens de 20 à 44 ans.

LIEU : L'échantillon ( $\mathrm{n}=2$ 962) provenait de six établissement canadiens.

CONCEPTION : On a effectué une étude de prévalence faisant appel au protocole de l'European Community Respiratory Health Survey. On a évalué l'obstruction des voies aériennes par spirométrie. On a également mesuré la réactivité bronchique, la réactivité cutanée aux allergènes et les taux élevés d'immunoglobuline E totale. Pour l'analyse, on a fait appel à la régression logistique.

RÉSULTATS : On a observé une obstruction des voies aériennes chez $6,4 \%$ de l'échantillon de population, sans lien avec le sexe ou l'âge. Le risque d'obstruction des voies aériennes augmentait chez les patients qui avaient fumé et chez ceux qui avaient eu des troubles pulmonaires pendant l'enfance. Rajusté compte tenu du tabagisme, le risque d'obstruction des voies aériennes était élevé pour les sujets qui avaient été ou étaient asthmatiques, présentaient une réactivité cutanée aux allergènes et des taux élevés d'immunoglobuline E totale et d'hyperréactivité bronchique. Chez les sujets souffrant d'obstruction des voies aériennes, $21 \%$ étaient des fumeurs ayant des antécédents d'asthme, $50 \%$, des fumeurs non asthmatiques, $12 \%$, des non-fumeurs asthmatiques et $17 \%$, des non-fumeurs non asthmatiques. L'hyperréactivité bronchique accentuait la prévalence d'obstruction des voies aériennes dans chacun de ces groupes.

CONCLUSION : Le tabagisme et l'asthme, conjointement et individuellement, sont des déterminants majeurs de troubles obstructifs chez les jeunes adultes. L'hyperréactivité bronchique contribue à l'obstruction au sein de ces deux groupes.

Key Words: Airway obstruction; Obstructive lung disease; Risk factors; Young adults

$A$ irflow obstruction is a hallmark of both chronic obstrucAtive pulmonary disease (COPD) and asthma. The former is defined as not fully reversible airflow limitation (1), while the latter is characterized by reversible airflow limitation that may become irreversible. Between 20 and 44 years of age, airflow obstruction may be a marker of important outcomes. Smokers with airflow obstruction at these ages are likely to develop COPD, while in asthmatics, the airflow obstruction may be irreversible. Both are major causes of morbidity and disability (1-3). Most asthma develops at an early age (4), and although the prevalence of COPD and associated mortality is low before 35 years of age, the origin of COPD may also be in childhood (5).

The aim of the present study was to estimate the prevalence and characteristics of airflow obstruction in a population sample of young adults (20 to 44 years of age) in Canada.

${ }^{1}$ University of Manitoba, Winnipeg, Manitoba; ${ }^{2}$ McGill University, Montreal, Quebec; ${ }^{3}$ Dalhousie University, Halifax, Nova Scotia; ${ }^{4}$ University of British Columbia, Vancouver, British Columbia; ${ }^{5} \mathrm{McM}$ aster University, Hamilton, Ontario; ${ }^{6}$ Prince Edward Island Department of Health and Social Services, Charlottetown, Prince Edward Island

Correspondence and reprints: Dr NR Anthonisen, University of Manitoba, Respiratory Hospital RS-319, 810 Sherbrook Street, Winnipeg,

Manitoba R3A 1R8. Telephone 204-787-2562, fax 204-787-4586, e-mail nanthonisen@exchange.hsc.mb.ca 


\section{Study subjects}

\section{PATIENTS AND METHODS}

Details of a multicentre, two-stage epidemiological study conducted in 1993 and 1994 in six locations (Vancouver, Winnipeg, Hamilton, Montreal, Halifax and Prince Edward Island [PEI]) across Canada were reported previously $(6,7)$. In the first stage, a short mail questionnaire about respiratory symptoms was sent to between 3000 and 4000 randomly selected adults, aged 20 to 44 years, in each site. Except in PEI, random digit dialing was used to identify eligible individuals. A random sample of 18,000 telephone numbers was generated for each location. Interviewers called the numbers and, following an appropriate introduction, determined whether the number was residential and the number of eligible subjects in the household. If there was no answer, the interviewer called up to seven times, varying the day and time called. A predetermined sampling scheme was used to select one resident if more than one household member was eligible. A short questionnaire about respiratory symptoms was sent to selected individuals, and repeated for nonresponders after three weeks. Those who did not respond to the second mailing were telephoned and encouraged to return the completed questionnaire by mail or to complete it over the telephone. In PEI, the procedure was the same except that eligible individuals were identified from a population registry of the provincial health plan. The total sample consisted of 21,449 subjects of whom $18,616(86.8 \%)$ completed the mail questionnare. In the second stage, a preselected random subsample of subjects who had responded to the mail questionnaire was examined in the laboratory with more detailed questionnaires, spirometry including the methacholine challenge test, determination of total immunoglobulin E (IgE) and skin testing with 14 allergens (8). In the vast majority, the time between the first and second stage was less than two months.

\section{Questionnaire}

Respiratory symptoms were obtained using the European Community Respiratory Health Survey (ECRHS) questionnaire (8). Chronic bronchitis was deemed present if cough and/or phlegm lasted for as long as three months of the year, and shortness of breath if it occurred when hurrying on level ground or when walking up a slightly inclined hill. A person was deemed asthmatic by a positive answer to the question, "Have you ever had asthma?" Current asthmatics were defined as having an attack within the past 12 months. Current smokers were defined as having smoked during the past month, while never smokers smoked less than 20 packs of cigarettes in their lives or less than one cigarette per day for a total of one year. Others were defined as past smokers. The lifetime exposure to tobacco was estimated in pack-years. Subjects were categorized by occupation (9) and by self-reported dust exposure.

\section{Spirometry}

Forced expiratory volume in $1 \mathrm{~s}\left(\mathrm{FEV}_{1}\right)$ and forced vital capacity (FVC) were measured using a dry rolling seal instrument (GrasbeAndersen, Spirotech Division, USA), and the protocol and software of the Lung Health Study (10). Airflow obstruction was defined by the lower limit of normality (LLN) for $\mathrm{FEV}_{1} / \mathrm{FVC}$ using Hankinson's equations (11). For comparison purposes, the Global Initiative for Chronic Obstructive Lung Disease (GOLD) definition of airflow obstruction ( $\mathrm{FEV}_{1} / \mathrm{FVC}$ less than $70 \%, \mathrm{FVC} \%$ predicted greater than $80 \%$ ) was used as well (1).

\section{Bronchial responsiveness}

Bronchial responsiveness was measured using methacholine administered with Mefar compressed-air dosimeters (MB3, Mefar, Italy) according to the ECRHS protocol (8).

The cumulative dose of methacholine producing a $20 \%$ decrease in $\mathrm{FEV}_{1}$ from the post-saline control $\left(\mathrm{PD}_{20}\right)$ was computed by plotting the decline in $\mathrm{FEV}_{1}$ against the logarithm of the cumulative dose of methacholine (12). $\mathrm{A} \mathrm{PD}_{20} 1 \mathrm{mg}$ or less indicated bronchial hyper-responsiveness. Bronchial responsiveness was also expressed as the logarithm of slope.

\section{Skin testing}

Each subject was prick tested, as described previously (7), with 14 allergens (Hollister-Stier Laboratories LLC, USA), a negative and a positive control. A wheal was considered to be positive if the average diameter was at least $2 \mathrm{~mm}$ greater than the diameter of the negative control.

Total IgE levels, determined using the Pharmacia kit (Phadia, USA) in the biochemistry laboratory of the Health Sciences Centre (Winnipeg, Manitoba), were considered elevated if they were higher than $100 \mathrm{kU} / \mathrm{L}(13,14)$.

\section{Analysis}

The prevalence (per cent) of airflow obstruction with 95\% CI was estimated. Nonparticipation was assessed by comparing participants to nonparticipants; the prevalence of airflow obstruction was adjusted for sex, age, smoking and wheezing by the direct method to the distribution of all subjects who completed the mail questionnaire. Differences between subjects with and without airflow obstruction were tested by $\chi^{2}$ (discrete variables) or $t$ tests (continuous variables). Logistic regression analysis was used to identify variables associated with airflow obstruction (15). Results were considered significant if $\mathrm{P}<0.05$. SAS software (SAS Institute Inc, USA) was used.

The study was approved by ethics review boards from all participating institutions.

\section{RESULTS}

Only $38.4 \%$ of invited subjects came to the laboratory, with substantial variation among sites $(24.6 \%$ to $57.5 \%)$. Compared with the sample as a whole, age and sex distribution were similar, but those attending were less likely to be smokers $(26.1 \%$ versus $32.2 \%, \mathrm{P}<0.001)$, and more likely to have reported symptoms of asthma (30.8\% versus $26.8 \%, \mathrm{P}<0.001)$. Because statistical adjustment for these differences did not change the results, nonadjusted rates are reported. A total of 2962 individuals participated in the laboratory examination with 2819 having acceptable quality lung function tests.

There were 186 individuals $(6.6 \%, 95 \%$ CI 5.7 to 7.6$)$ with $\mathrm{FEV}_{1} / \mathrm{FVC}$ less than the LLN (11), with little difference between men $(6.7 \%, 95 \%$ CI 5.5 to 8.2$)$ and women $(6.5 \%$, $95 \%$ CI 5.4 to 7.9 ). This was higher than the prevalence of airflow obstruction using the GOLD definition of $\mathrm{FEV}_{1} / \mathrm{FVC}$ less than $70 \%$ (1), $(4.2 \%, 95 \%$ CI 3.5 to 5.0$)$. This was because 66 individuals had $\mathrm{FEV}_{1} / \mathrm{FVC}$ below Hankinson's LLN but more than 0.70 . Only $1.5 \%$ (95\% CI 1.1 to 2.0 ) had FEV 1 less than $70 \%$ of predicted normal.

There were 393 individuals (13.9\%, 95\% CI 12.7 to 15.3 ) who had chronic bronchitis without airflow obstruction, with no difference between men and women. Adjusted for smoking, $\mathrm{FEV}_{1} / \mathrm{FVC}$ was slightly, although significantly $(\mathrm{P}=0.005)$, lower 
TABLE 1

Comparison of subjects with and without airflow obstruction

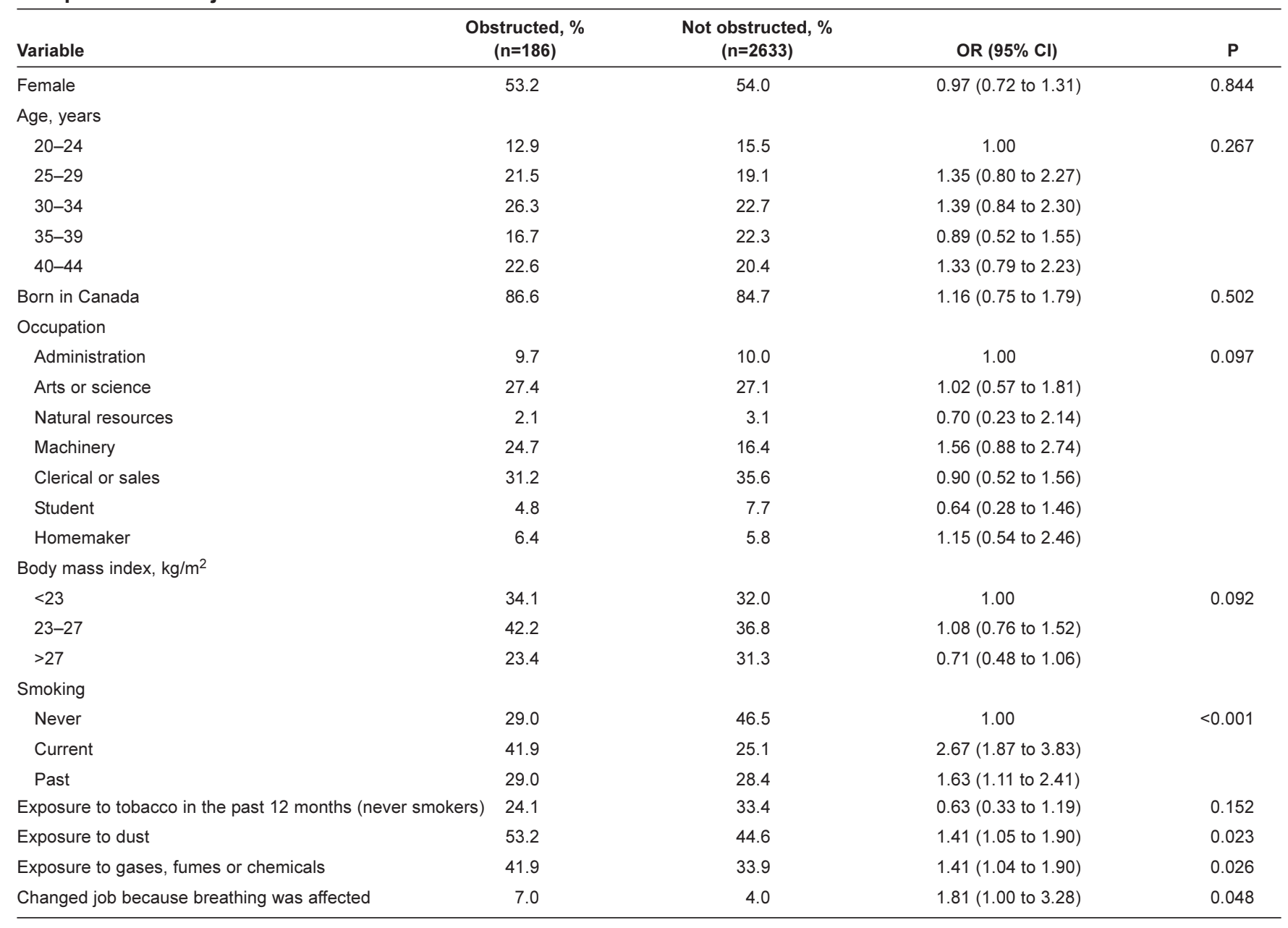

Data are presented as percentages of the total except for exposure to tobacco in the last 12 months, in which the number of obstructed never smokers is 54 and of not obstructed subjects is 1223. Airflow obstruction is defined as forced expiratory volume in 1 s/forced vital capacity less than the lower limit of normality (11)

(0.82) in subjects with chronic cough and sputum (GOLD 0) than in those without symptoms (0.83).

As shown in Table 1, airflow obstruction was not associated with age, sex, body mass index, country of birth or occupation; however, it was associated with occupational exposure to dust, gases and fumes, and with current or past smoking. Excluding subjects who reported a history of asthma, smokers with airflow obstruction averaged 3.5 pack-years more $(\mathrm{P}=0.019)$ than smokers without airflow obstruction. Never smokers with airflow obstruction were not more likely to have been exposed to environmental tobacco smoke in the past 12 months.

Table 2 shows that airflow obstruction was associated with asthma attacks, allergies, use of asthma medications, respiratory symptoms, health care use for respiratory disease and respiratory problems in childhood. Medication use was associated with a history of asthma (Table 2), but there was no significant difference between asthmatics and nonasthmatics with airflow obstruction in relation to emergency room visits and hospitalizations (data not shown).

Of 2819 eligible subjects, total serum IgE levels were obtained for $83.0 \%$ of patients, skin tests for $94.4 \%$ of patients and $79.5 \%$ of patients were challenged with methacholine (7). Sufficient data to approximate $\mathrm{PD}_{20}$ using the ECRHS program (12) were available for 2241 subjects (98.4\%) who underwent the methacholine challenge test. The relationship between risk factors and airflow obstruction was essentially the same for all subjects and for the subset with measurements of bronchial responsiveness.

Airflow obstruction was strongly associated with bronchial hyper-responsiveness (Table 3), elevated total IgE levels and increased skin test reactivity to allergens.

Variables significantly associated with airflow obstruction in Tables 1-3 are also shown in a univariate model in Table 4. These variables were fitted into multiple logistic regression models to determine their independent effects on airflow obstruction.

The most explanatory models of a series of models examined are presented in Table 4. Smoking was strongly significant in all multivariable models. Model 1 indicates that the effect of fume and dust exposure was confounded by smoking, as was respiratory infection before five years of age confounded by lung trouble before 16 years of age. The strong univariate effect of the variable 'ever had asthma' diminished by one-half when current asthma was in the same model. Model 2 shows that the addition of skin reactivity to allergens and total IgE did not have a major effect on the relationship between the variables in model 1 and airflow obstruction, although the effect of asthma was slightly reduced. Total IgE was not associated with 
TABLE 2

Current and past medical history: A comparison of subjects with and without airflow obstruction

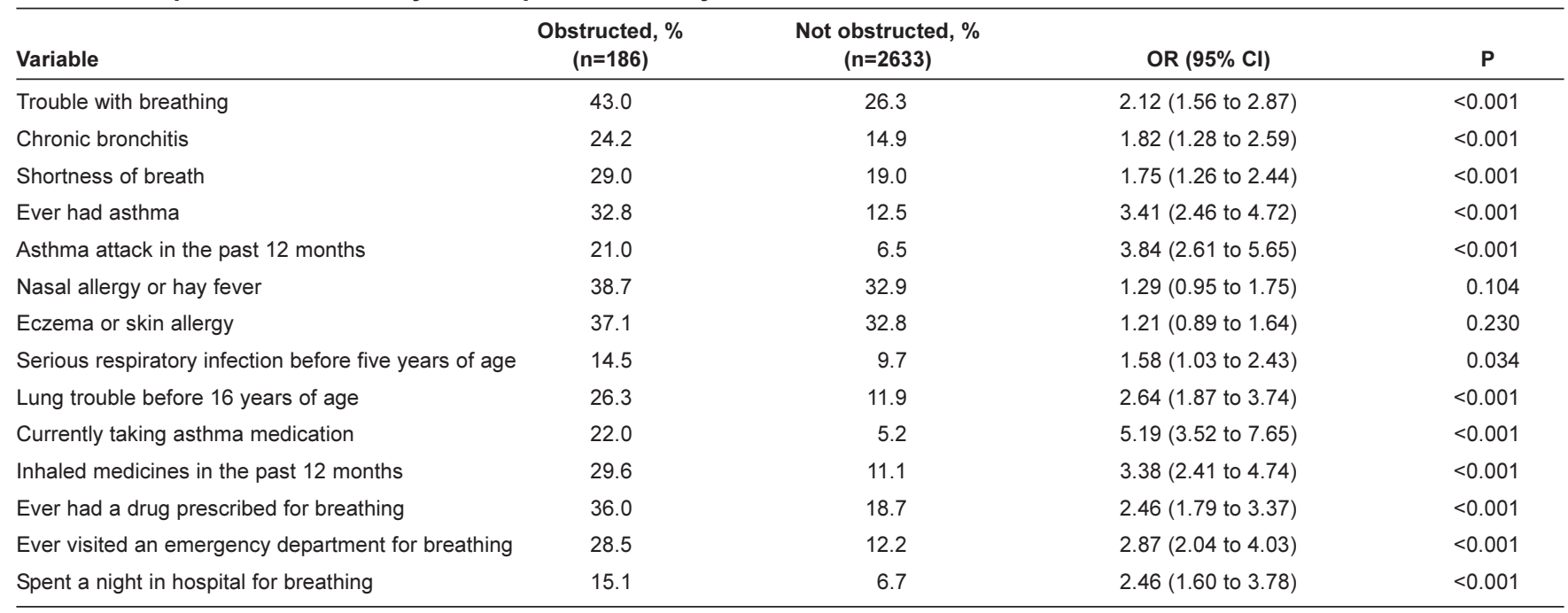

Data are presented as percentages of the total. Airflow obstruction is defined as forced expiratory volume in 1 s/forced vital capacity less than the lower limit of normality (11)

TABLE 3

Distribution of bronchial hyper-responsiveness ( $\mathrm{PD}_{20} 1 \mathrm{mg}$ or less), total immunoglobulin $\mathrm{E}$ and skin test reactivity: A comparison between subjects with and without airflow obstruction

\begin{tabular}{|c|c|c|c|c|}
\hline Variable & Obstructed, n (\%) & Not obstructed, n (\%) & OR $(95 \% \mathrm{Cl})$ & $\mathbf{P}$ \\
\hline \multicolumn{5}{|l|}{$\mathrm{PD}_{20}, \mathrm{mg}$} \\
\hline$\leq 1$ & 56 of $129(43.4)$ & 242 of $2112(11.5)$ & 5.93 (4.08 to 8.61$)$ & $<0.001$ \\
\hline \multicolumn{5}{|c|}{ Immunoglobulin E, U/L } \\
\hline$<30$ & 68 of $158(43.0)$ & 1154 of 2181 (52.9) & 1.00 & 0.003 \\
\hline $30-99$ & 44 of $158(27.9)$ & 628 of $2181(28.8)$ & $1.19(0.80$ to 1.76$)$ & \\
\hline$\geq 100$ & 46 of $158(29.1)$ & 399 of $2181(18.3)$ & 1.96 (1.32 to 2.89$)$ & \\
\hline None & 50 of $176(28.4)$ & 951 of 2485 (38.3) & 1.00 & $<0.001$ \\
\hline Any & 126 of $176(71.6)$ & 1534 of $2485(61.7)$ & 1.75 (1.24 to 2.46$)$ & \\
\hline
\end{tabular}

Data are presented as percentages of the total. Airflow obstruction is defined as forced expiratory volume in 1 s/forced vital capacity less than the lower limit of normality (11). $P D_{20}$ Dose of methacholine producing a $20 \%$ decrease in forced expiratory volume in $1 \mathrm{~s}$ from the post-saline control

TABLE 4

Variables associated with airflow obstruction in young adults

\begin{tabular}{|c|c|c|c|c|}
\hline \multirow[b]{2}{*}{ Variable } & \multirow{2}{*}{$\begin{array}{c}\text { Univariate model } \\
\text { OR }(95 \% \mathrm{Cl})\end{array}$} & \multicolumn{3}{|c|}{ Multivariable models* } \\
\hline & & Model 1, OR (95\% Cl) & Model 2, OR (95\% Cl) & Model 3, OR (95\% Cl) \\
\hline Current smoking & 2.7 (1.9 to 3.8$)$ & 2.6 (1.8 to 3.8$)$ & 2.7 (1.9 to 4.0$)$ & 2.7 (1.6 to 2.3 ) \\
\hline Dust exposure & $1.4(1.1$ to 1.9$)$ & NS & - & - \\
\hline Respiratory infection before five years of age & $1.6(1.0$ to 2.4$)$ & NS & - & - \\
\hline Lung trouble before 16 years of age & 2.6 (1.9 to 3.7$)$ & $1.6(1.1$ to 2.5$)$ & $1.6(1.0$ to 2.4$)$ & NS \\
\hline Current asthma & $3.8(2.6$ to 5.7$)$ & $1.9(1.1$ to 3.5$)$ & $1.8(1.0$ to 3.3$)$ & NS \\
\hline Bronchial hyper-reactivity & 5.9 (4.1 to 8.6$)$ & - & - & $5.3(3.4$ to 8.4$)$ \\
\hline Allergy & $1.9(1.3$ to 2.6$)$ & - & $1.6(1.2$ to 2.2$)$ & NS \\
\hline Immunoglobulin E & $2.0(1.3$ to 2.9$)$ & - & NS & - \\
\hline
\end{tabular}

${ }^{*}$ ORs were adjusted for all variables in the model in addition to sex and age. All significant univariate variables except bronchial hyper-reactiviy, allergy and immunoglobulin E were entered into model 1. In model 2, allergy and immunoglobulin E were added to significant variables in model 1. In model 3, bronchial hyperreactivity was added to the significant variables in model 2. '-' The variable was not fit into the model; NS Not significant 
TABLE 5

The relationship between bronchial hyper-responsiveness ( $\mathrm{PD}_{20} 1 \mathrm{mg}$ or less) and airflow obstruction

\begin{tabular}{|c|c|c|c|c|c|c|c|c|}
\hline \multirow[b]{2}{*}{ Group } & \multirow[b]{2}{*}{ Total, $\mathbf{n}$} & \multirow{2}{*}{$\begin{array}{c}\mathrm{PD}_{20} \leq 1 \mathrm{mg} \\
\mathrm{n}(\%)\end{array}$} & \multirow{2}{*}{$\begin{array}{l}\mathrm{AO}+ \\
\text { n (\%) }\end{array}$} & \multicolumn{2}{|c|}{$\mathrm{PD}_{20} \leq 1 \mathrm{mg}$} & \multicolumn{2}{|c|}{$\mathrm{PD}_{20}>1 \mathrm{mg}$} & \multirow[b]{2}{*}{ OR $(95 \% \mathrm{Cl})$} \\
\hline & & & & $\overline{A O+, n}$ & AO-, n & $\overline{A O+, n}$ & $A O-, n$ & \\
\hline Never smoking, never asthma & 887 & $69(7.8)$ & $26(2.9)$ & 8 & 61 & 18 & 800 & $5.83(2.43$ to 13.95$)$ \\
\hline Never smoking, asthma & 116 & $46(39.7)$ & $11(9.5)$ & 8 & 38 & 3 & 67 & 4.70 (1.18 to 18.79$)$ \\
\hline Smoking, asthma & 172 & $70(30.0)$ & $25(14.5)$ & 21 & 49 & 4 & 98 & 10.50 (3.41 to 32.27 ) \\
\hline
\end{tabular}

Airflow obstruction is defined as forced expiratory volume in 1 s/forced vital capacity less than the lower limit of normality (11). AO+ Airflow obstruction; AO- No airflow obstruction; $P D_{20}$ Dose of methacholine producing a $20 \%$ decrease in forced expiratory volume in $1 \mathrm{~s}$ from the post-saline control

airflow obstruction when allergies were included in the model. Bronchial hyper-responsiveness (model 3) had a major effect on the OR of airflow obstruction. The effects of current asthma, lung trouble before 16 years of age and skin reactivity became insignificant when bronchial hyper-responsiveness was fit into the model.

Table 4 suggests that smoking, asthma and bronchial hyperresponsiveness were the independent explanatory variables for airflow obstruction in young adults.

Subjects were separated into four groups according to a history of smoking and asthma (Table 5). In comparison with those who never smoked and never had asthma, smoking alone significantly increased the prevalence of both bronchial hyperresponsiveness $(7.8 \%$ to $10.6 \%, \mathrm{P}=0.032)$ and airflow obstruction $(2.9 \%$ to $6.3 \%, \mathrm{P}=0.001)$. The prevalence of both disorders was the highest in subjects with a history of both smoking and asthma. Table 5 further shows that bronchial hyper-responsiveness was significantly associated with airflow obstruction in all four groups. Although the risk of airflow obstruction associated with bronchial hyper-responsiveness in subjects with a history of both smoking and asthma was almost twice as high as other groups, the interactive terms of smoking and asthma with bronchial hyper-responsiveness were not significant, suggesting that the effect of bronchial hyper-responsiveness was additive to the effect of smoking and asthma.

\section{DISCUSSION}

There are two major strengths of the present study. First, it estimated the prevalence and risk factors of airflow obstruction in a random sample of young adults. Second, the study protocol (8) allows for comparison of results with other studies (16).

There was no evidence that the participation rate of $38.4 \%$ in stage 2 of the study biased the findings of the study. Adjustment for variables that were significantly different between participants and nonparticipants (smoking and symptoms) did not change the prevalence of airflow obstruction; nonadjusted rates are reported to facilitate comparison with results from the international sites of the ECRHS (16). Bronchial responsiveness was not determined for approximately $20 \%$ of subjects. This did not bias the results either, because the relationship of variables in model 1 (obtained from the questionnaire and available for all subjects) to airflow obstruction did not differ for subjects with and without bronchial responsiveness.

Airway obstruction was defined as an $\mathrm{FEV}_{1} / \mathrm{FVC}$ less than the LLN of Hankinson et al (11). While any such definition is arbitrary, this may be more appropriate than the GOLD definition of less than 0.70 , which is lower than Hankinson's criterion in young adults. The Hankinson's LLN reflects the lower bounds for $95 \%$ of a normal (nonsmoking) population; therefore, one may expect $5 \%$ of a normal population to fall below these limits. Only $6.6 \%$ of study subjects had airflow obstruction as defined. This is not much more than was expected in a normal population. On the other hand, the study subjects were not a normal population, including smokers and asthmatics, and more importantly, the individuals identified using the arbitrary definition of airflow obstruction were distinctly different from those without airflow obstruction. Even nonsmoking nonasthmatics who had an $\mathrm{FEV}_{1} / \mathrm{FVC}$ below the LLN demonstrated significantly higher rates of bronchial hyper-responsiveness than nonsmoking nonasthmatics without airflow obstruction. The arbitrary definition of airflow obstruction that we used had objective meaning.

The prevalence of airflow obstruction defined by Hankinson's prediction equations (11) was 6.6\%, and was not related to sex and age. The lower prevalence of airflow obstruction using the definition by GOLD was due to Hankinson's LLN of $\mathrm{FEV}_{1} / \mathrm{FVC}$ exceeding 0.70 in some subjects. Using the definition by GOLD, the prevalence of airflow obstruction in the present study was slightly higher $(4.2 \%)$ than the median $(3.6 \%)$ for 16 ECRHS countries (16). Our data are consistent with both ECRHS (16) and surveys in the United States (17), which found that in the developed world, there is a substantial prevalence of airflow obstruction in young adults. Data in Table 2 suggest that it is not a trivial disorder.

The relationship between risk factors and airflow obstruction in the present study must be interpreted carefully because it was assessed using a cross-sectional design. While this design identifies variables associated with current cases of airflow obstruction, it can only suggest, because of a lack of temporal relationship, that these variables were responsible for the development of the disorder.

Smoking was a major independent risk factor for airflow obstruction. The small difference in smoking exposure between smokers with and without airflow obstruction (3.5 pack-years) suggested that airflow obstruction at this age chiefly reflected unusual sensitivity to smoking (18). In never smokers, contrary to the ECRHS study (16), there was no effect of environmental exposure to tobacco. The relationship between environmental tobacco smoke and decreased lung function is not consistent and the effect on lung function is relatively small (19).

The effect of self-reported exposure to dust, fumes and gases was not independent of smoking, although the literature supports the role of occupational exposures in the development of airflow obstruction (20-22). These findings may be the result 
of the healthy worker effect (23), or due to the lack of prolonged exposure or inaccurate reporting.

The finding that elevated levels of IgE were not associated with airflow obstruction independent of asthma and positive skin reactivity is consistent with the literature $(24,25)$; allergies were, however, significantly correlated with asthma (both ever and current) and with lung trouble before 16 years of age. Because both allergy and asthma related independently to airflow obstruction, presumably reflected that some asthma is not associated with allergy.

Bronchial hyper-responsiveness was strongly $(\mathrm{OR}=5.9)$ associated with airflow obstruction. This effect was not substantially diminished when other variables were in the model $(\mathrm{OR}=5.3)$ (Table 4). The effects of current asthma, lung trouble before 16 years of age and allergies were not significant in the presence of bronchial hyper-responsiveness. The effects of having asthma previously were retained and had an effect on airflow obstruction; apparently some previous asthmatics had normal methacholine reactivity.

It is conceivable that the relationship between bronchial hyper-responsiveness and airflow obstruction was due to increased responsiveness of people with small airway calibre, ie, low $\mathrm{FEV}_{1}$ (26). In the present study, there was a significant relationship between $\mathrm{FEV}_{1}$ expressed as per cent of predicted value and bronchial responsiveness expressed as logarithm of slope, but the correlation was poor $(\mathrm{r}=0.24)$ because of scatter. When the analysis was restricted to subjects with airflow obstruction, there was little improvement in the correlation; $\mathrm{FEV}_{1}$ accounted for less than $10 \%$ of the variation in bronchial responsiveness. We believe that bronchial hyperresponsiveness was, to some extent, independent of $\mathrm{FEV}_{1}$ and that it conveyed useful information. This is compatible with several longitudinal studies (27-29) showing that bronchial hyper-responsiveness increased the risk of airflow obstruction as well as being its consequence.

The combination of smoking and asthma accounted for $21 \%$ of subjects with airflow obstruction, smoking alone for $50 \%$ of subjects with airflow obstruction, and asthma alone for

\section{REFERENCES}

1. Pauwels RA, Buist AS, Calverley PM, Jenkins CR, Hurd SS; for the GOLD Scientific Committee. Global strategy for the diagnosis, management, and prevention of chronic obstructive pulmonary disease. NHLBI/WHO Global Initiative for Chronic Obstructive Lung Disease (GOLD) Workshop summary. Am J Respir Crit Care Med 2001;163:1256-76.

2. European Community Respiratory Health Survey. Variations in the prevalence of respiratory symptoms, self-reported asthma attacks, and use of asthma medication in the European Community Respiratory Health Survey (ECRHS). Eur Respir J 1998;9:687-95.

3. The International Study of Asthma and Allergies in Childhood (ISAAC) Steering Committee. Worldwide variations in the prevalence of asthma symptoms: The International Study of Asthma and Allergies in Childhood (ISAAC). Eur Respir J 1998; 12:315-35.

4. Yunginger JW, Reed CE, O'Connell EJ, Melton LJ III, O'Fallon WM, Silverstein MD. A community-based study of the epidemiology of asthma. Incidence rates, 1964-1983. Am Rev Respir Dis 1992;146:888-94

5. Shaheen $\mathrm{S}$. The beginnings of chronic airflow obstruction. Br Med Bull 1997;53:58-70.

6. Manfreda J, Becklake MR, Sears MR, et al. Prevalence of asthma symptoms among adults aged $20-44$ years in Canada. CMAJ 2001;164:995-1001.

7. Manfreda J, Sears MR, Becklake MR, et al. Geographic and gender variability in the prevalence of bronchial responsiveness in Canada. Chest 2004;125:1657-64.
$12 \%$ of subjects with airflow obstruction. However, $17 \%$ of those with airway obstruction never smoked and had no history of asthma. Bronchial hyper-responsiveness increased the risk of airflow obstruction in all four categories including the latter. It was not possible to identify any significant risk factors other than bronchial hyper-responsiveness in this group.

In the present study, airway obstruction in young adults was associated with two well-known risk factors: smoking and asthma. Most individuals could be characterized as either having early COPD or asthma; however, such a dichotomous analysis may be an oversimplification for several reasons. First, a substantial fraction of subjects with airway obstruction both had smoked and had a history of asthma; whether these subjects will subsequently develop clinical COPD or remain 'asthmatic' is unknown. It should be noted that this is the group with the highest prevalence of airflow obstruction (14.5\%) (Table 5) and, when coupled with a high level of hyper-responsiveness, may indicate a poor prognosis. Second, bronchial hyper-responsiveness was an important risk factor of airway obstruction in both asthmatics and smokers. Methacholine reactivity is both a characteristic of asthma and a predictor of lung function decline in smokers. It is not clear, however, that the mechanism of bronchial hyper-responsiveness is the same in smokers and asthmatics; the clinical characteristics of nonsmoking asthmatics and smokers with the same level of methacholine reactivity are thought to be quite different. Finally, a significant fraction of our young adults with airway obstruction had bronchial hyper-responsiveness but were neither smokers nor known asthmatics; the subsequent course of the disease in these people is also unknown, but may be important to our understanding of clinical obstructive lung disease.

ACKNOWLEDGEMENT: Support was provided by the National Health Research and Development Program, Health Canada; GlaxoSmithKline Canada (an unrestricted grant to the University of Manitoba); and the province of Prince Edward Island.

8. European Commission, Directorate General XII. Protocol for the European Community Respiratory Health Survey. Luxembourg: Office for Official Publications, 1993.

9. Statistics Canada. Standard Occupational Classification (SOC) 1991. Ottawa: Statistics Canada, Standards Division, 1993. <http://www.statcan.ca/english/Subjects/Standard/soc/1991/soc91index.htm $>$ (Version current at April 26, 2007).

10. Enright PL, Johnson LR, Connett JE, Voelker H, Buist AS. Spirometry in the Lung Health Study. 1. Methods and quality control. Am Rev Respir Dis 1991;143:1215-23.

11. Hankinson JL, Odencrantz JR, Fedan KB. Spirometric reference values from a sample of the general US population. Am J Respir Crit Care Med 1999;159:179-87.

12. Chinn S, Burney P, Jarvis D, Luczynska C. Variation in bronchial responsiveness in the European Community Respiratory Health Survey (ECRHS). Eur Respir J 1997;10:2495-501.

13. Holford-Strevens V, Warren P, Wong C, Manfreda J. Serum total immunoglobulin E levels in Canadian adults. J Allergy Clin Immunol 1984;73:516-22.

14. Burrows B, Martinez FD, Halonen M, Barbee RA, Cline MG. Association of asthma with serum IgE levels and skin-test reactivity to allergens. N Engl J Med 1989;320:271-7.

15. Armitage P, Berry G, Mathews JNS. Statistical Methods in Medical Research, 4th edn. Oxford: Blackwell Science, 2002.

16. de Marco R, Accordini S, Cerveri I, et al. An international survey of chronic obstructive pulmonary disease in young adults according to GOLD stages. Thorax 2004;59:120-5. 
17. Mannino DM, Homa DM, Akabami LJ, Ford ES, Redd SC. Chronic obstructive pulmonary disease surveillance - United States, 1971-2000. Surveillance Summaries, August 2, 2002. MMWR 2002;51:1-16.

18. Sandford AJ, Weir TD, Pare PD. Genetic risk factors for chronic obstructive pulmonary disease. Eur Respir J 1997;10:1380-91.

19. Chan-Yeung M, Dimich-Ward H. Respiratory health effects of exposure to environmental tobacco smoke. Respirology 2003;8:131-9. (Erratum in 2005;10:553).

20. Becklake MR. Chronic airflow limitation: Its relationship to work in dusty occupations. Chest 1985;88:608-17.

21. Becklake MR. Occupational exposures: Evidence for a causal association with chronic obstructive pulmonary disease. Am Rev Respir Dis 1989;140:S85-91.

22. Burge PS. Occupation and chronic obstructive pulmonary disease (COPD). Eur Respir J 1994;7:1032-4.

23. Becklake MR, Lalloo U. The 'healthy smoker': A phenomenon of health selection? Respiration 1990;57:137-44.

24. Burrows B, Knudson RJ, Cline MG, Lebowitz MD. A reexamination of risk factors for ventilatory impairment. Am Rev Respir Dis 1988;138:829-36.
25. Sherrill DL, Lebowitz MD, Halonen M, Barbee RA, Burrows B. Longitudinal evaluation of the association between pulmonary function and total serum IgE. Am J Respir Crit Care Med 1995;152:98-102.

26. Tashkin DP, Altose MD, Bleecker ER, et al. The lung health study: Airway responsiveness to inhaled methacholine in smokers with mild to moderate airflow limitation. Am Rev Respir Dis 1992;145:301-10.

27. Rijcken B, Schouten JP, Xu X, Rosner B, Weiss ST. Airway hyperresponsiveness to histamine associated with accelerated decline in $\mathrm{FEV}_{1}$. Am J Respir Crit Care Med 1995;151:1377-82.

28. O'Connor GT, Sparrow D, Weiss ST. A prospective longitudinal study of methacholine responsiveness as a predictor of pulmonary-function decline: The Normative Aging Study. Am J Respir Crit Care Med 1995;152:87-92.

29. Tashkin DP, Altose MD, Connett JE, Kanner RE, Lee WW, Wise RA. Methacholine reactivity predicts changes in lung function over time in smokers with early chronic obstructive pulmonary disease. The Lung Health Study Research Group. Am J Respir Crit Care Med 1996;153:1802-11. 


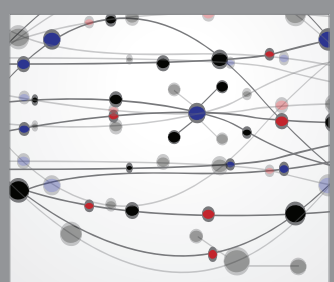

The Scientific World Journal
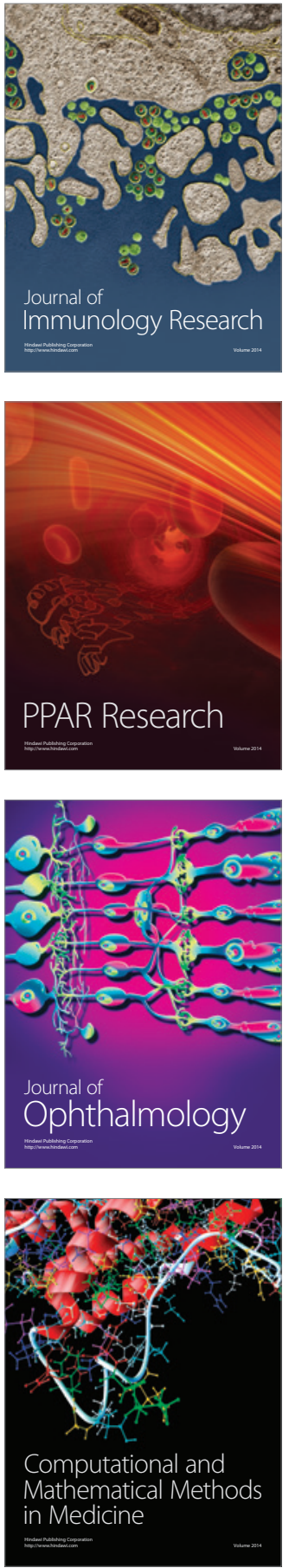

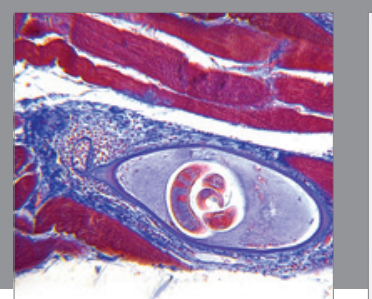

Gastroenterology Research and Practice

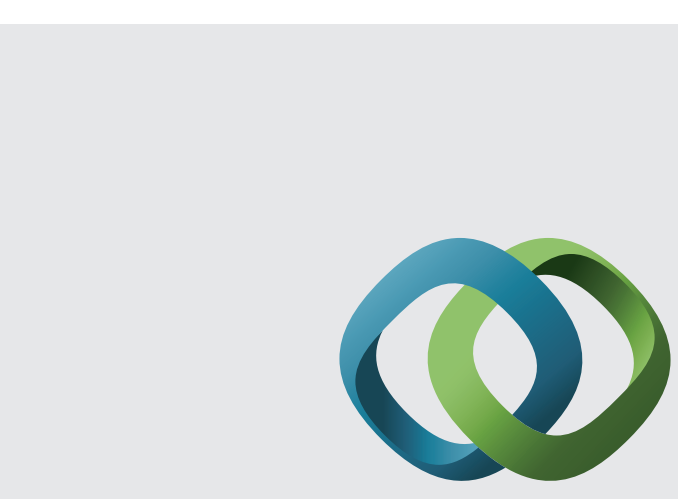

\section{Hindawi}

Submit your manuscripts at

http://www.hindawi.com
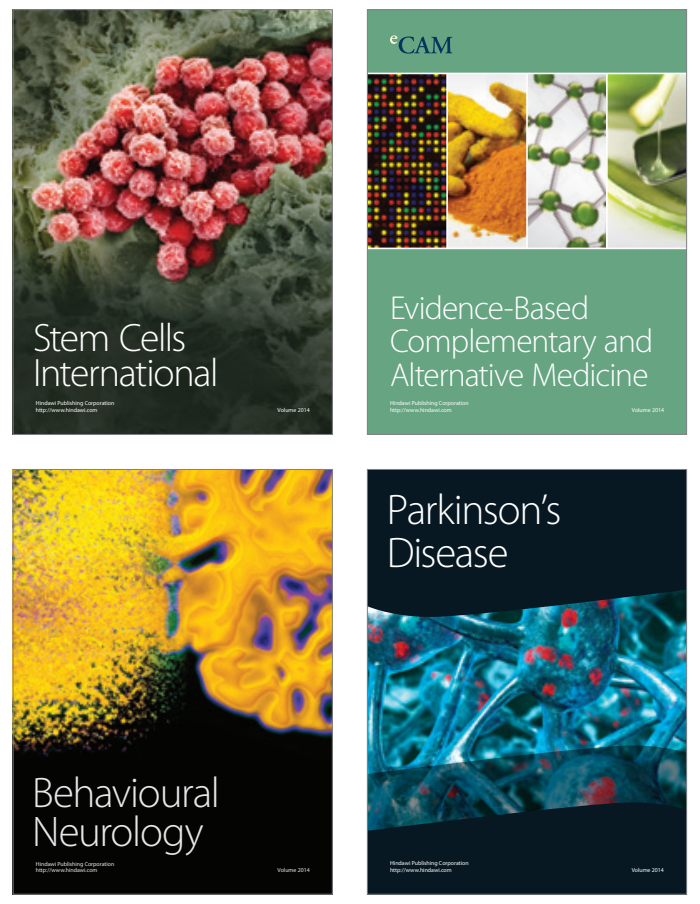
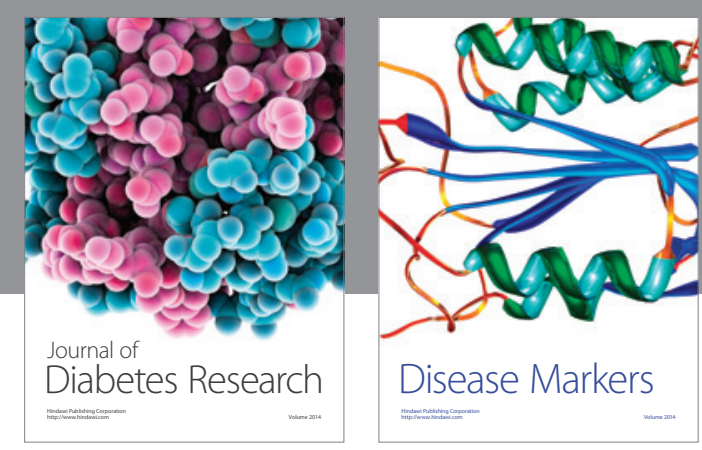

Disease Markers
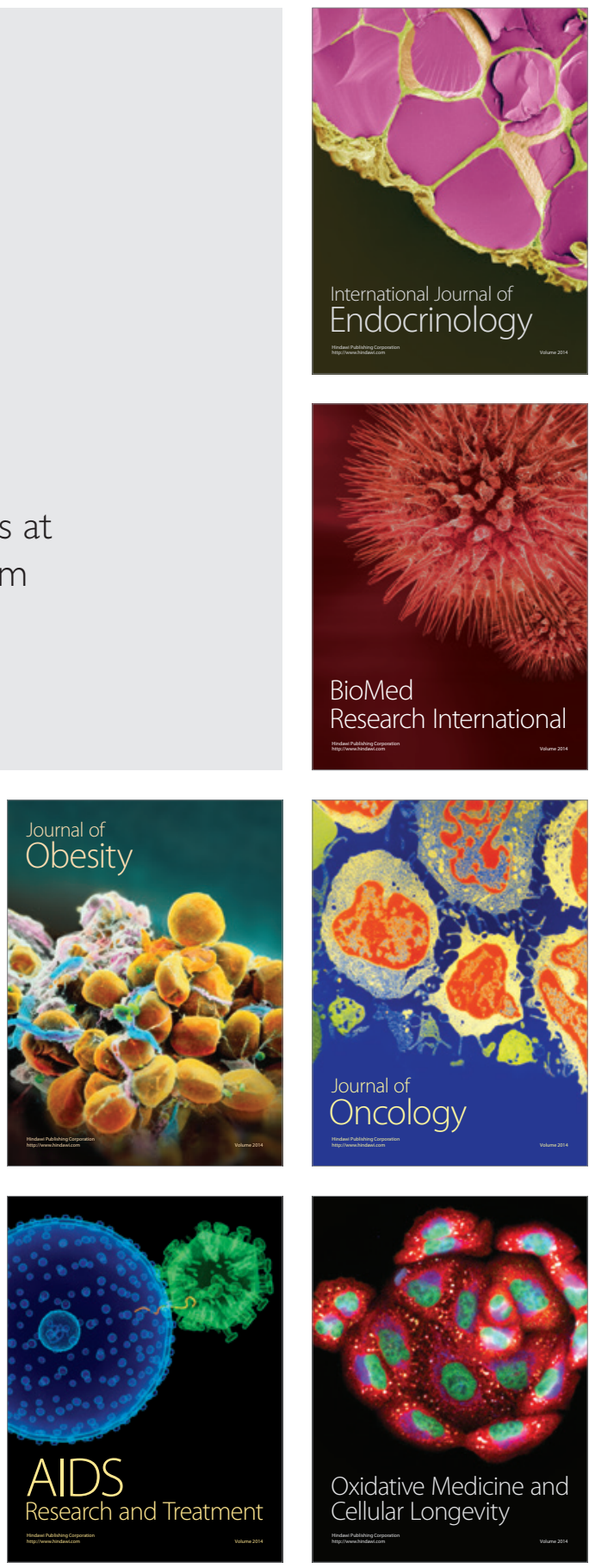